\title{
Factors controlling the release of arsenic from mining tailings
}

\author{
B. E. Rubio-Campos ${ }^{1}$, I. Cano-Aguilera ${ }^{1}$, \\ A. F. Aguilera-Alvarado ${ }^{1}$, G. De la Rosa ${ }^{1}$ \& S. H. Soriano-Pérez ${ }^{2}$ \\ ${ }^{I}$ Department of Chemical Engineering, University of Guanajuato, Mexico \\ ${ }^{2}$ Department of Chemical Sciences, \\ Autonomous University of San Luis Potosi, Mexico
}

\begin{abstract}
Some mine tailings pools in the Mine District of Guanajuato, Mexico, present a varied distribution and temporal and spatial concentration of elements that are potentially toxic, such as manganese, cadmium and zinc. These elements were detected in majority concentrations, and arsenic was present in the two major oxidation states $\mathrm{As}(\mathrm{III})$ and $\mathrm{As}(\mathrm{V})$. The highest arsenic concentration in the surrounding surface water reservoirs was detected when a rainy seasons occurred, which in turn is mainly a function of $\mathrm{pH}$ and the presence of bicarbonate ions. The conceptual model to describe the mobilization of arsenic from mining tailings towards the aqueous systems proposes a scenario where oxidation, the neutralization of acid drainage by carbonates, and arsenic desorption by bicarbonates takes place in different steps and at different times. Keywords: mining tailings, potentially toxic elements, arsenic release.
\end{abstract}

\section{Introduction}

The mining district of Guanajuato is located $475 \mathrm{~km}$ from Mexico City. It is considered one of the largest worldwide. However, large amounts of mining tailings, which result from crushing and milling ore, once they have been recovered through commercial metal physical or chemical processes, have been generated over time [1]. These can be transported and become a severe environmental problem in relation to soil, sediment, surface water and groundwater pollution [2]. 
Mining Tailings of San Nicolas Mine (JSN) and mining tailings of Peregrina Mine $(J P)$ are both located in this district and are already abandoned. Under certain physico-chemical, geological and biological conditions they can promote the leaching and transportation of metals to aqueous systems. Several studies have been carried out aimed at different purposes: the identification of potentially toxic elements in leaching experiments of mining tailings [3]; geological and mineralogical characterization of mining tailings [4]; and the arsenic potential release from mining tailings [5]. In this context and in order to explain the presence of arsenic and other toxic elements in water from Presa de Mata, it is important to locate and characterize the source of the pollution and the factors that are controlling this event.

\section{Methodology}

\subsection{Sampling and characterization of mining tailings in this study}

\subsubsection{Sampling, preservation and transportation of mining tailings in this study}

Mining tailing samples of $2 \mathrm{k}$ were collected from the surface and from $10 \mathrm{~cm}$ deep [6]. The choice of the place and sampling sites carried out depended on local conditions and ease of access to sampling points. Once in the laboratory all samples were air dried and sieved to homogenize them. Sampling was performed at three different seasonal times, corresponding to an abundant precipitation season (August 2007), a dry cold season (February 2008) and a dry season (July, 2009). The sampling of mining tailings of Peregrina mine was carried out only in the dry season (July, 2009).

\subsubsection{Physico-chemical analysis of samples of mining tailings in this study}

Granulometric analysis was performed. Subsequently, the physico-chemical properties - humidity percent, real density, bulk density, porosity and $\mathrm{pH}$ - were measured. For the determination of arsenic (As), cadmium $(\mathrm{Cd})$, lead $(\mathrm{Pb})$, manganese $(\mathrm{Mn})$, and zinc $(\mathrm{Zn})$, the mining tailing samples were digested in a microwave oven (Perkin Elmer, Multiware 3000) [7]. Element analyses were determined by flame atomic absorption spectroscopy (FAAS) (Perkin Elmer, AAnalyst 100). The hydride generation technique was coupling to FAAS for arsenic determination.

A speciation spectrum of arsenic by X-ray Absorption Spectroscopy was obtained. The collected samples of JSN packaged subsequently were analyzed beamline 7-3 at the Stanford Synchrotron Radiation Laboratory (SSRL) in Menlo Park, CA.

\subsubsection{Mineralogical analyses of samples of mining tailings in this study}

Four samples of $10 \mathrm{~g}$ of mining tailing samples in this study were dried and sieved $(J S N$ and $J P)$; later the samples were concentrated using a solution of sodium dodecyl sulfate (SDS) in order to eliminate the high silica content. Two of these samples' mineralogical composition were obtained using an X-ray 
diffractometer (Siemens D-500) with a copper anode $(\lambda=1.5418 \AA)$ operated at $30 \mathrm{kV}$ and $20 \mathrm{~mA}$. Another two samples were determined by elemental qualitative analyses by $\mathrm{X}$-ray fluorescence, using an X-ray spectrometer (Siemens SRS-200) operated at $40 \mathrm{kV}$ and $30 \mathrm{mV}$.

\subsubsection{Acid-base balance of samples of mining tailings in this study}

The potential of acidity (PA) of the mining tailings was obtained, quantifying sulfides as the difference between total sulphur and sulfates. The potential of neutralization $(\mathrm{PN})$ was obtained by the reaction of the mining tailings with sequential additions of $\mathrm{HCl}$ and $\mathrm{pH}$ after 2, 22 and $24 \mathrm{~h}$. Finally the net potential of neutralization $(\mathrm{PNN})$ was calculated by:

$$
P N N=\frac{P N}{P A}
$$

When the relationship (1) is less than 1.2 the tailings are generators of acid rock drainage, otherwise they do not generate acid rock drainage.

\subsection{Sampling and characterization of aqueous samples of the main tributaries to Presa de Mata}

\subsubsection{Sampling, preservation and transport of potentially toxic elements from aqueous samples of the main tributaries to Presa de Mata}

Collection containers ( 11 approximately) were rinsed two or three times with the liquid to take as a sample [8]. Aqueous samples were acidified with nitric acid until a $\mathrm{pH}$ of less than or equal to 2.0 was obtained for metal analyses. The aqueous samples for anions determination were refrigerated until the analyses (sulfates, chlorides, carbonates-bicarbonates).

\subsubsection{Physico-chemical analyses of potentially toxic elements in aqueous samples from the main tributaries to Presa de Mata}

The $\mathrm{pH}$ and temperature of water samples in situ were measured using a Corning Checkmate II Modular Meter System, in accordance with the instructions of the manufacturer. Element concentration of water samples were determined by FAAS. The hydride generation technique was coupled for each arsenic determination. The following anions, sulfates, chlorides, carbonates and bicarbonates were also determined.

\subsection{Leaching of potentially toxic elements of mining tailings in this study}

\subsubsection{Leaching of potentially toxic elements of mining tailings in a batch system}

Samples of $J P$ were used and contacted with different leachate solutions, in order to simulate different conditions that may be carried out. The leachate solutions employed were: acidified water $\mathrm{pH} 4,9 \mathrm{~K}$ culture medium, and bacteria growing in $9 \mathrm{~K}$ cultured medium [9]; the final concentration of each array was $20 \mathrm{mg}$ mining tailings $/ \mathrm{ml}$ solution. For each experiment, $40 \mathrm{ml}$ of each array were placed in conical polypropylene tubes in triplicate. The tubes were 
incubated for 1, 3, 5, 7 and 14 days in agitation at room temperature. Metals in the solution were determined. The metals analyzed were: As, Cd, Mn, Ag, Pb and $\mathrm{Zn}$.

\subsubsection{Leaching of potentially toxic elements of mining tailings in a continuous system}

Samples of mining tailings, $J S N$ and $J P$, were dried at room temperature previously, sieved $(<0.5 \mathrm{~mm})$ and packed in glass columns of $4 \mathrm{~cm}$ in diameter and $16 \mathrm{~cm}$ high. Nitric acid solution $(\mathrm{pH} 4 \pm 0.1-$ maximum $2 \mathrm{ppb}$ of metal impurities) was introduced in an up stream flow using a peristaltic pump at 12 and $9 \mathrm{ml} / \mathrm{min}$ for packed columns with samples of $J S N$ and $J P$, respectively. Five fractions of leachate of each column by triplicate were collected at different times [10]. Each fraction was collected over the top of the column. The parameters in the leachate: $\mathrm{pH}$, oxide-reduction potential, electrical conductivity were registered. The concentration of elements was determined by FAAS and As was determined by hydride generation coupling to FAAS.

\section{Results and discussion}

\subsection{Sampling and characterization of mining tailing samples in this study}

\subsubsection{Sampling, preservation and transportation of mining tailing samples in this study}

A map of microwatershed Peregrina-Presa de Mata-Monte de San Nicolas is displayed in fig. 1. This was created with Arcview GIS version 3.2 and shows

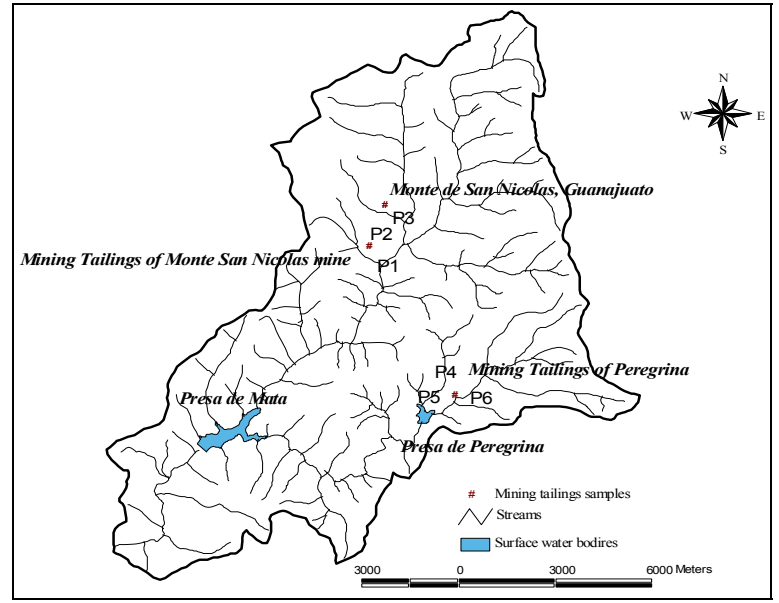

Figure 1: Microwatershed Monte de San Nicolas-Presa de Mata-Peregrina, Guanajuato. Mining tailing sampling points are located in (P) places. 
the main surface water bodies towards Presa de Mata, as well as the points of the mining tailing samples. Georeferenced points: P1, P2, P3 and P4, represent sampling sites of JSN and P5 and P6 represent sampling sites of JP.

\subsubsection{Physico-chemical analysis of mining tailing samples in this study}

The physico-chemical parameters of the mining tailing samples determined are displayed in table 1.

Samples of $J P$ showed a fine particle size. This feature is important for oxidation processes because it allows better oxygen diffusion, water conduction and interaction with other reactive phases.

Element concentrations in $J S N$ and $J P$ and their respective standard deviations are shown in tables 2 and 3 , respectively.

Table 1: $\quad$ Physico-chemical parameters determined in mining tailing samples.

\begin{tabular}{|c|c|c|c|c|c|}
\hline $\begin{array}{c}\text { Sample } \\
(\mathrm{P})\end{array}$ & $\begin{array}{c}\text { Real density } \\
\left(\mathrm{g} / \mathrm{cm}^{3}\right)\end{array}$ & $\begin{array}{c}\text { Bulk density } \\
\left(\mathrm{g} / \mathrm{cm}^{3}\right)\end{array}$ & Porosity & $\begin{array}{c}\text { Humidity } \\
(\%)\end{array}$ & $\mathrm{pH}$ \\
\hline 1 & 2.97 & 1.01 & 0.79 & 0.274 & 7.60 \\
\hline 2 & 2.86 & 1.38 & 0.52 & 0.102 & 7.21 \\
\hline 3 & 3.22 & 1.01 & 0.68 & 0.274 & 6.08 \\
\hline 4 & 2.87 & 0.92 & 0.67 & 0.288 & 7.08 \\
\hline 5 & 2.22 & 1.05 & 0.52 & 0.110 & 6.00 \\
\hline 6 & 2.20 & 1.03 & 0.50 & 0.103 & 6.03 \\
\hline
\end{tabular}

Table 2: $\quad$ Concentration of elements in mining tailings JSN.

\begin{tabular}{|c|c|c|c|c|c|}
\hline Sampling season & $\mathrm{As}(\mathrm{mg} / \mathrm{k})$ & $\mathrm{Mn}(\mathrm{mg} / \mathrm{k})$ & $\mathrm{Zn}(\mathrm{mg} / \mathrm{k})$ & $\mathrm{Cd}(\mathrm{mg} / \mathrm{k})$ & $\mathrm{Pb}(\mathrm{mg} / \mathrm{k})$ \\
\hline August 2007 & $4.8 \pm 0.004$ & $638.9 \pm 0.025$ & $219.11 \pm 3.25$ & No detected & $34.82 \pm 0.04$ \\
\hline February 2008 & $21.7 \pm 0.020$ & $1030.1 \pm 0.001$ & $266.77 \pm 3.1$ & $2.58 \pm 0.006$ & $63.85 \pm 0.11$ \\
\hline July 2009 & $11.1 \pm 0.011$ & $1960.3 \pm 0.001$ & $278.52 \pm 1.2$ & $3.33 \pm 0.003$ & $101.8 \pm 0.005$ \\
\hline
\end{tabular}

Table 3: $\quad$ Concentration of elements in mining tailings $J P$.

\begin{tabular}{|c|c|c|c|c|c|}
\hline Sampling season & $\mathrm{Pb}(\mathrm{mg} / \mathrm{k})$ & $\mathrm{As}(\mathrm{mg} / \mathrm{k})$ & $\mathrm{Mn}(\mathrm{mg} / \mathrm{k})$ & $\mathrm{Zn}(\mathrm{mg} / \mathrm{k})$ & $\mathrm{Cd}(\mathrm{mg} / \mathrm{k})$ \\
\hline February 2008 & $86.99 \pm 0.15$ & $14.0 \pm 0.005$ & $1388.2 \pm 0.001$ & $484.19 \pm 0.9$ & $2.21 \pm 0.004$ \\
\hline July 2009 & $75.04 \pm 0.25$ & $17.22 \pm 0.017$ & $1165.3 \pm 0.001$ & $379.12 \pm 1.5$ & $2.57 \pm 0.009$ \\
\hline
\end{tabular}

The total As contents ranged between 4.8 and $11.1 \mathrm{mg} / \mathrm{k}$. This concentration does not exceed the permissible maximum limit $(L M P)$ for As, which corresponds to $22 \mathrm{mg} / \mathrm{k}$ [11], but the potential risk is presented because there are variations of arsenic concentrations over time and space. Concentrations of $\mathrm{Mn}$ show diversity in time and space. The $\mathrm{Zn}$ contents in all concentrations exceed the Canadian Standards [12]. The $\mathrm{Pb}$ contents ranged between 34.8 and 101.8 $\mathrm{mg} / \mathrm{k}$. In rainy seasons the presence of $\mathrm{Cd}$ was not detected. The concentration of elements in $J S N$ occurs in the following sequence: $\mathrm{Mn}>\mathrm{Zn}>\mathrm{Pb}>\mathrm{As}>\mathrm{Cd}$.

The major elements in $J P$ were $\mathrm{Mn}$ and $\mathrm{Zn}$. The As contents ranged between 14 and $17.22 \mathrm{mg} / \mathrm{k}$, showing a greater concentration in the dry season. Therefore, the concentration of elements in JSN presents the same sequence of that in samples of the Monte de San Nicolas mine, but in a higher proportion. 


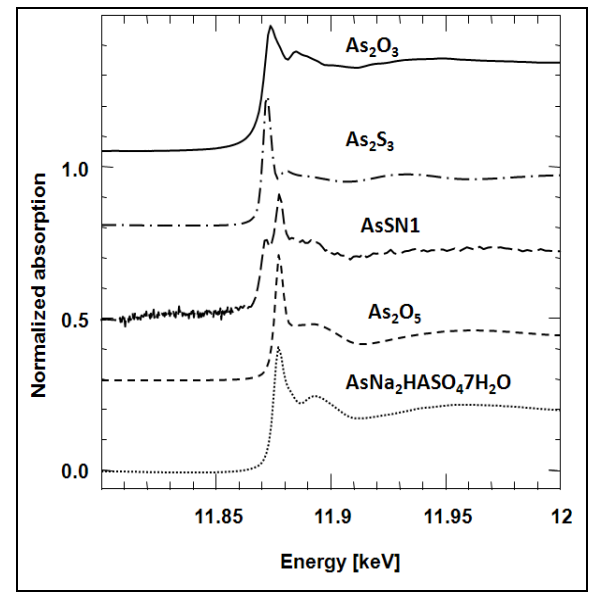

Figure 2: $\quad$ Spectra of X-ray absorption for sample of $J S N$ for As (AsSN1). Model compounds: $\mathrm{As}_{2} \mathrm{O}_{3}, \mathrm{As}_{2} \mathrm{~S}_{3}, \mathrm{As}_{2} \mathrm{O}_{5}$ y $\mathrm{AsNa}_{2} \mathrm{HAsO}_{4} 7 \mathrm{H}_{2} \mathrm{O}$.

Table 4: $\quad$ Mineralogical analyses of mining tailings samples in this study by $\mathrm{X}$-ray diffraction.

\begin{tabular}{|c|c|c|c|}
\hline \multicolumn{2}{|c|}{$J S N$} & \multicolumn{2}{c|}{$J P$} \\
\hline Phases identified & Possible phases & Identified phases & Possible phases \\
\hline Quartz $\mathrm{SiO}_{2}$ & Smectite $\mathrm{Fe}_{2} \mathrm{O}_{3}$ & Quartz $\mathrm{SiO}_{2}$ & Hematite $\mathrm{Fe}_{2} \mathrm{O}_{3}$ \\
Calcite $\mathrm{CaCO}_{3}$ & Calcite $\mathrm{CaCO}_{3}$ & \\
Plagioclase $\mathrm{NaAlSi}_{3} \mathrm{O}_{8}$ & & Ortoclase $\mathrm{KAlSi}_{3} \mathrm{O}_{8}$ & \\
Clinochlore & & Plagioclase $\mathrm{NaAlSi}_{3} \mathrm{O}_{8}$ & \\
$\mathrm{Mg}_{5} \mathrm{Al}_{\left(\mathrm{Si}_{3} \mathrm{Al}\right) \mathrm{O}_{10}(\mathrm{OH})_{8}}$ & & Smectite (montmorillonite) & \\
Muscovite $\mathrm{KAl}_{2} \mathrm{Si}_{3} \mathrm{AlO}_{4}(\mathrm{OH})_{2}$ & & Kaolinita $\mathrm{Al}_{2} \mathrm{Si}_{2} \mathrm{O}_{5}(\mathrm{OH})_{4}$ & \\
\hline
\end{tabular}

Spectra of several model compounds for As and JSN are shown in fig. 2. This figure shows displacement in absorption energy for As(V) and As(III). The As from mining tailing samples (ASSN1 in the spectrum) displays two absorption energies for the same element. The first line threshold occurs at $11,867 \mathrm{keV}$ and the second at $11,875 \mathrm{keV}$. This corresponds to the presence of As(III) and As(V), respectively.

\subsubsection{Mineralogical analyses of mining tailing samples from Monte San Nicolas and Peregrina mines}

The results of the X-ray diffraction are displayed in table 4. This table shows that the materials present a typical mineralogical composition of mining tailings. It was not possible to identify the presence of metal sulfides, given such high levels in the content and crystallization of the quartz and calcite minerals present.

Elemental qualitative analyses by $\mathrm{X}$-ray fluorescence show that $J S N$ and $J P$ are constituted by $\mathrm{Fe}, \mathrm{Ca}, \mathrm{Sr}, \mathrm{Zn}$ and $\mathrm{Rb}$. Both samples contain $\mathrm{Fe}$ as the majority element, which is typical of mineral composition; also these samples consist of calcium, which reflected the high content of carbonates and that contribute to neutralize the degree of acidity, reducing the acid rock drainage. 


\subsubsection{Acid-base balance of mining tailings samples in this study}

The determination of the acid rock drainage of tailings due to their reactivity can be determined by the oxidation of sulfide. The results are presented in table 5 . These results suggest that the mining tailings in this study are not acid generators of acid rock drainage; this is possibly due to the high amount of carbonates containing mining waste and that they somehow contribute to neutralize the degree of acidity that is generated or generated since the age of abandonment of the mining tailings and processes that could have been carried out.

Table 5: Determination of acid rock drainage in the mining tailings.

\begin{tabular}{|c|c|c|c|}
\hline Sample & $\begin{array}{c}\text { PN } \\
\left(\mathrm{Kg} \mathrm{CaCO}_{3} / \text { ton mining tailings }\right)\end{array}$ & $\begin{array}{c}\text { PA } \\
\left(\mathrm{Kg} \mathrm{CaCO}_{3} / \text { ton mining tailings }\right)\end{array}$ & $(\mathrm{PNN})$ \\
\hline P1 & 77.0 & 7.75 & 9.93 \\
\hline P2 & 76.0 & 7.7 & 9.87 \\
\hline P3 & 82.5 & 7.06 & 11.69 \\
\hline P4 & 80.8 & 7.02 & 11.42 \\
\hline P5 & 175.0 & 4.86 & 36.04 \\
\hline P6 & 185.0 & 4.13 & 44.75 \\
\hline
\end{tabular}

\subsection{Sampling and characterization of aqueous samples in the main tributaries to Presa de Mata}

\subsubsection{Sampling, preservation and transport of potentially toxic elements from aqueous samples in the main tributaries to Presa de Mata}

A map of microwatershed Presa de Mata, Guanajuato and its main tributaries is presented in fig. 3, where sampling points are indicated for various seasonal times. The sampled surface water bodies are located "downstream" from deposits of mining tailings, which are considered as sources of pollution.

The results of potentially toxic elements corresponding to three seasons of sampling in the stream from Monte de San Nicolas to Presa de Mata showed that the As contents ranged between 0.012 and $0.015 \mathrm{mg} / \mathrm{l}$, which is within Mexican Standards [13], but is not within the limit recommended by international guidelines, since chronic exposure to As causes toxic effects to human health. These results suggest that detected elements can be leachated from mining tailings and transported by main streams to Presa de Mata. In the case of the dry season and abundant rainfall, samples have higher concentrations of As. High concentrations of $\mathrm{Mn}$ are detected. $\mathrm{Pb}$ and $\mathrm{Zn}$ were only identified in the dry season (July, 2009) and rainy season (August, 2007), respectively. The $\mathrm{Pb}$ contents exceeds the $L M P$, while the $\mathrm{Zn}$ content is lower than this standard. Water samples from Peregrina to Presa de Mata corresponding to July 2009 presented high values of both As and Mn.

Variation of $\mathrm{pH}$ in the study sites for sampling in the dry season ranged between 7 and 8; this indicates a neutral environment to slightly alkaline, which can be explained by the presence of carbonates in samples of tailings that neutralize the degree of acidity that could occur. The temperature registered ranged between 19 and $24{ }^{\circ} \mathrm{C}$.

Concentrations of anions were determined by following established guidelines in the Mexican Standards. The results are displayed in table 6, which 


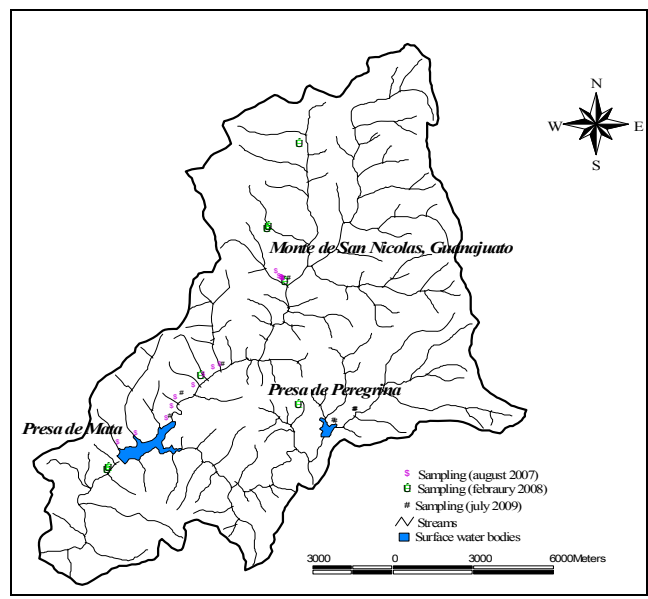

Figure 3: Microwatershed Monte de San Nicolas-Presa de Mata-Peregrina, Guanajuato. Sampling points are shaded in gray.

Table 6: $\quad$ Anions in water samples (July, 2009).

\begin{tabular}{|c|c|c|c|c|}
\hline & Sample & $\mathrm{Cl}^{-}(\mathrm{mg} / \mathrm{l})$ & $\mathrm{HCO}_{3}{ }^{-}(\mathrm{mg} / \mathrm{l})$ & $\mathrm{SO}_{4}{ }^{2-}(\mathrm{mg} / \mathrm{l})$ \\
\hline \multirow{3}{*}{$\begin{array}{c}\text { Stream from Monte } \\
\text { San Nicolas to }\end{array}$} & 1 & $38.67 \pm 7.4$ & $162.7 \pm 3.7$ & $85.1 \pm 1.8$ \\
\cline { 2 - 5 } $\begin{array}{c}\text { Presa } \\
\text { de Mata }\end{array}$ & 2 & $38.67 \pm 3.7$ & $162.7 \pm 3.7$ & $128.6 \pm 1.5$ \\
\cline { 2 - 5 } & 3 & $32.23 \pm 3.7$ & $162.7 \pm 3.7$ & $98.2 \pm 1.4$ \\
\cline { 2 - 5 } & 5 & $32.23 \pm 7.4$ & $122.0 \pm 3.7$ & $311.4 \pm 1.3$ \\
\cline { 2 - 5 } & 6 & $32.67 \pm 7.4$ & $122.0 \pm 3.7$ & $387.5 \pm 1.9$ \\
\cline { 2 - 5 } $\begin{array}{c}\text { Stream from } \\
\text { Peregrina to }\end{array}$ & 7 & $38.67 \pm 3.7$ & $122.0 \pm 0.005$ & $447.3 \pm 1.8$ \\
\cline { 2 - 5 } Presa de Mata & 8 & $38.67 \pm 3.7$ & $203.3 \pm 0.005$ & $154.7 \pm 1.5$ \\
\cline { 2 - 5 } & 9 & $32.23 \pm 3.7$ & $122.0 \pm 0.005$ & $190.5 \pm 1.4$ \\
\cline { 2 - 5 } & 10 & $38.67 \pm 3.7$ & $203.3 \pm 0.005$ & $447.3 \pm 1.3$ \\
\hline
\end{tabular}

correspond to streams from Monte San Nicolas and Peregrina mining tailing sites, respectively.

\subsection{Leaching of potentially toxic elements of mining tailing samples from Monte San Nicolas and Peregrina mines}

\subsubsection{Leaching of potentially toxic elements of mining tailings from Peregrina mine in the batch system}

Fig. 4 shows the concentration of As leachate depending on the time, for different leachate solutions. In this figure, As was leachated in low amounts when a $9 \mathrm{~K}$ medium and bacteria type Thiobacillus ferrooxidans, previously selected from mining tailings and grown in a $9 \mathrm{~K}$ culture medium, was used as a leachate solution. The continuous line represents the initial concentration of total As in the sample of mining tailings.

The leaching kinetic of $\mathrm{Cd}$ is displayed in fig. 5. Cd was leachated efficiently, since more than $90 \%$ of mining tailings were detected in the solution. The continuous line represents the initial concentration of the total $\mathrm{Cd}$ in the sample of mining tailings. 


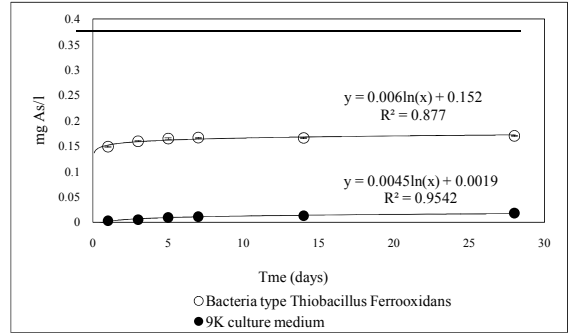

Figure 4: As leaching mining tailings in batch system.

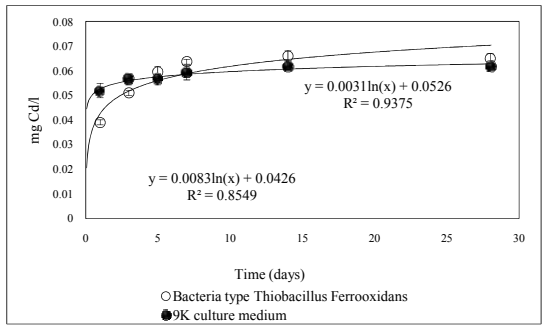

Figure 5: Cd leaching from mining tailings in the batch system.

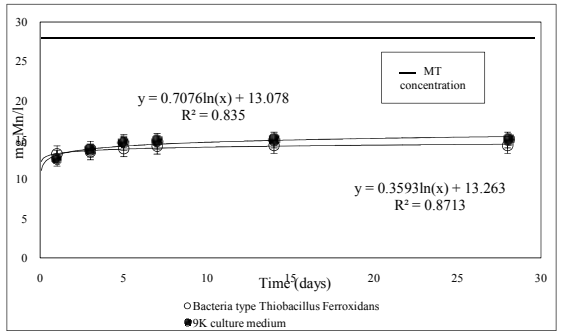

Figure 6: Mn leaching from mining tailings in the batch system. 
For $\mathrm{Mn}$, the leachate solution with bacteria was fitted to a logarithmic function as shown in fig. 6, where the trend line represents this behavior and points to the experimental data. The continuous line represents the initial concentration of total $\mathrm{Mn}$ in the sample of mining tailings.

The $\mathrm{Pb}$ leaching kinetic using $9 \mathrm{~K}$ medium was fitted to a logarithmic function, while for $\mathrm{Zn}$ with bacteria type Thiobacillus ferrooxidans it was fitted to a linear function (these data are not shown). These results suggest that there are special sceneries that promote the leaching of potentially toxic elements and when these are combined in the natural system, their concentrations are higher in aqueous systems.

\subsubsection{Leaching of toxic potentially elements of mining tailing samples in this study}

The kinetics of As leaching in continuous systems as a function of time are displayed in fig. 7.

Each point represents the As released from mining tailings estimated by the difference between the total As concentration in the mining tailings and the As concentration detected in solution. In both cases the observed trend is logarithmic.

The variation of Mn concentration in the leachated solution and the fitted functions are shown in fig. 8. This figure shows that the concentration of $\mathrm{Mn}$ released from $J S N$ is less than $\mathrm{Mn}$ from $J P$.

The $\mathrm{Zn}$ content in the solution and the fitted function are displayed in fig. 9. This element was obtained in higher concentration in comparison with other potentially toxic elements detected in the same system.

\section{Conclusions}

Mining tailing deposits from Monte San Nicolas and Peregrina showed a wide distribution and temporal and spatial concentration of potentially toxic elements, such as $\mathrm{Mn}, \mathrm{Cd}$ and $\mathrm{Zn}$ in majority concentrations, as well as As. Arsenic is present in the two oxidation states (III) and (V).

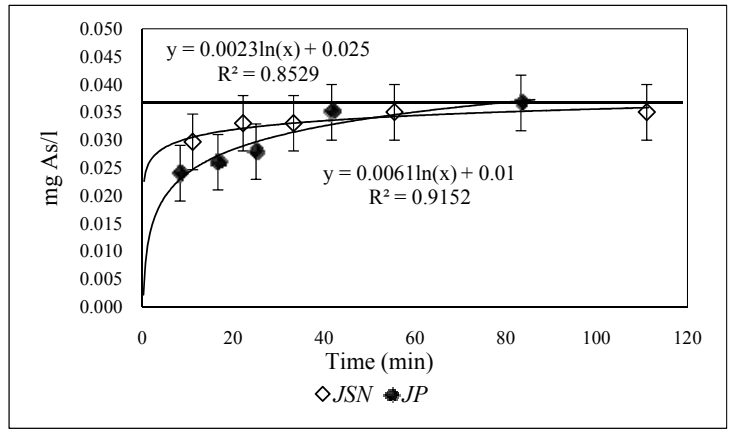

Figure 7: As leaching from mining tailings in a continuous system. 


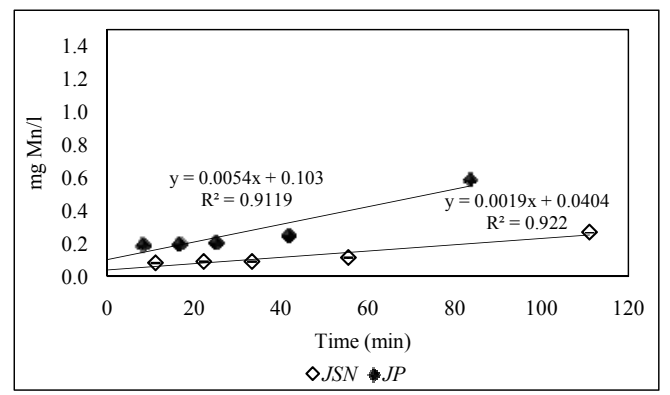

Figure 8: Mn leaching from mining tailings in the continuous system.

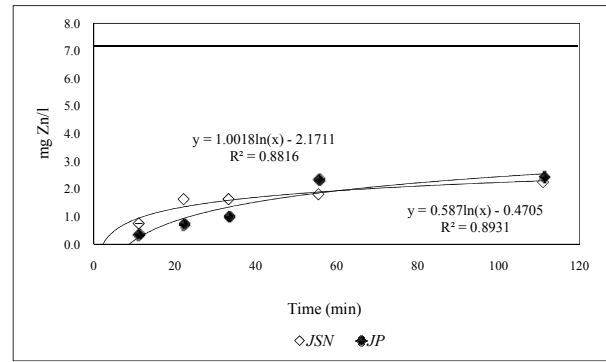

Figure 9: Zn leaching from mining tailings in the continuous system.

During rainy seasons, arsenic was obtained in higher concentration as a product of leaching of this element, which is a function of $\mathrm{pH}$ and the presence of bicarbonates in the system.

The $\mathrm{pH}$ of mining tailings in this study ranged between 6 and 8 , which demonstrated that mining waste possesses a high amount of carbonates that reduce the degree of acidity that could generate the due porosity and granulometry of mining tailings.

Microbial activity can leach considerably potentially toxic elements, mainly those such as $\mathrm{Cd}$.

The kinetics of leaching obtained in batch tests showed linear and logarithmic tendencies for $\mathrm{Zn}$ and As in continuous tests, respectively.

\section{References}

[1] Medel, A., Ramos, S., Avelar, F. J., Godínez, L. A., \& Rodríguez, F., Caracterización de Jales Mineros y evaluación de su peligrosidad con base en su potencial de lixiviación. Revistas Cientificas de América Latina y el Caribe, España y Portugal. 35, pp. 33-35, 2008. 
[2] Armienta, M. A., Villaseñor, G., Rodríguez, R. \& Mango, H. The role of arsenic-bearing rocks in groundwater pollution at Zimapán Valley, Mexico. Environmental Geology, 40(4, 5), pp. 571-581, 2001.

[3] Morton-Bermea, O., Carrillo-Chávez, A., Hernández, E. \& GonzálezPartida, E. Determination of Metals for Leaching Experiments of Mine Tailings: Evaluation of the Potential Environmental Hazard in the Guanajuato Mining District, Mexico. Bulletin of Environmental Contamination \& Toxicology. 73(4), pp. 770-776, 2004.

[4] Ramos-Arroyo, Y. R., Siebe-Grabach, C. D. Características geológicas y mineralógicas e historia de extracción del Distrito de Guanajuato, México. Posibles Escenarios geoquímicos para los residuos mineros Revista Mexicana de Ciencias Geológicas. 21(2), pp. 268-284, 2004.

[5] Ramos-Arroyo, Y. R. \& Siebe-Grabach, C. D. Estrategia para identificar jales con potencial de riesgo ambiental en un distrito minero: estudio del caso en el Distrito de Guanajuato, Mexico. Revista Mexicana en Ciencias Geológicas. 23(1), pp. 54-74, 2006.

[6] NOM-141-SEMARNAT-2003, Online. www.semarnat.gob.mx/ leyesynormas/Normas\%20Oficiales\%20Mexicanas\%20vigentes/NOM_141 SEMAR_03_13_SEP_04.pdf

[7] Microwave Assisted Acid Digestion of Sediments, Sludges, Soils, and Oils U. S. Environmental Protection Agency, 3051 method. Online. www.epa.gov/waste/hazard/testmethods/index.htm

[8] NMX-AA-014-1980, Receiver bodies sampling, Online. www.semarnat.gob.mx/leyesynormas/Normas\%20Mexicanas\%20vigentes/ NMX-AA-014-1980.pdf

[9] Silverman, M. P., Lundgren, D. G., Studies on the chemoautothropic iron bacterium Ferrobacillus ferrooxidans: an improved medium and a harvesting procedure of securing high cells yields. Journal of Bacteriology. 77, pp. 642-647, 1959.

[10] Netherlands Normalization Institute (1993b) NEN 7343, Leaching Characteristics of Building on Solid Waste Materials-Leaching Tests Determination of the Leaching of Inorganic Components from Granular Materials with the Column Test, The Netherlands.

[11] NOM-147-SEMARNAT/SSA1-2004, Que establece criterios para determinar las concentraciones de remediación de suelos contaminados por arsénico, bario, berilio, cadmio, cromo hexavalente, mercurio, níquel, plata, plomo, selenio, talio $\mathrm{y} / \mathrm{o}$ vanadio. Online. www.semarnat.gob.mx/ leyesynormas/normasoficialesmexicanasvigentes/Elaboracin $\% 20$ conjunta $\%$ 20\%20con\%20otras\%20secretarias/NOM_147_SEMARNAT_SSA1_2004. pdf

[12] Canadian Soil Quality Guidelines for the Protection of Environmental and Human Health (1996), Online. www.intranet2.minem.gob.pe/web/archivos/ dgaam/estudios/lazanja/Anexo_R.pdf

[13] NOM-127-SSA1-1994-2000, Norma Oficial Mexicana, Salud Ambiental agua para uso y consumo humano. Online. ww.salud.gob.mx/unidades/cdi/ nom/127ssa14.html 